\title{
USING THE RELATIVE STRENGTH INDEX FOR ACTIVE INVESTMENTS IN THE FOREIGN EXCHANGE MARKET
}

\begin{abstract}
The Foreign Exchange market is constantly affected by a huge amount of economic and political events, such as decisions of Central banks, changes of various economic ratios, elections, official announcements of country leaders, etc. Various investors, financiers and scientists had created many economic ratios, mathematical formulas and investing strategies to help improve the results of investments in financial instruments. The paper presents and discusses the data collected using the American analyst's Welles Wilder's Relative Strength Index in spot trades of the European Euro and the United States dollar pair. All data has been gathered from 01-01-2016 to 01-07-2017 and analyzed from a few points of view. The aim of this research is to find the best Relative Strength Index modification for trading in FOREX market. The research departed from classic Relative Strength Index to more sensitive modifications of original formula.Eight trading scenarios have been investigated with eight different Relative Strength Index modifications. Only one of them had positive result on return despite most of scenarios had the accuracy above 50\%. The article analyzes the reasons of trading losses also. The index was wrong when strong fundamental factors such as speeches of the ECB and FED heads took place. These mistakes brought trading losses of more than $2 \%$ unprofitability each. All work was based on the literature analysis of different authors from different countries and information from the FOREX brokers.
\end{abstract}

Keywords: financial markets, FOREX, Relative Strength Index.

\section{INTRODUCTION}

Since the first financial products appeared on the market, people have been trying to make a profit or save their capital by trading these products. Various approaches and theories have been developed to evaluate the risks, future value, future profit or loss. Despite many of the existing approaches, financial instruments need new ones. The reasons for that are new risks, new products and new technological possibilities for researching. The main ways to make a decision to invest in a financial market are fundamental and technical analyses. In 1978 Welles Wilder invented the Relative Strength Index (RSI). It has become very

\footnotetext{
${ }^{1}$ Ceslovas Bartkus, MSc, Faculty of Social Sciences, Panevezys University of Applied Sciences, Laisves a. 23, Panevezys LT-35200, Lithuania;e-mail: ceslovas.bartkus@panko.lt. ORCID: 0000-0003-4023-6627.

Mgr Ceslovas Bartkus, Wydział Nauk Społecznych, Uniwersytet Nauk Stosowanych w Poniewieżu, Laisves a. 23, Poniewież, LT-35200, Litwa; e-mail: ceslovas.bartkus@panko.lt. ORCID: 0000-0003-4023-6627.
} 
popular and widely used among technical analysts. Originally this index was created for stock market predictions. However, the methodology of the RSI calculation allows us to use it in other financial markets; such as the Foreign Exchange market (FOREX). FOREX is the biggest of the markets of financial products with a daily turnover of 4-5 trillion dollars. One of the attributes of this market is the high price volatility. From the point of view of securities trader, this type of volatility forces you to monitor the FOREX instruments daily or hourly. In other words, an investor has to be very active and react to changes in the market. This article presents the results of active trading between the European Euro and the US dollar (EUR/USD) currency pair with various interpretations of RSI. The biggest difference from W. Wilder's RSI is that this indicator is also used on hourly charts. Meanwhile, the author recommends doing this on daily charts. The main aim of the research is to find the best RSI modification for active trading in the FOREX market. Along with this result the paper seeks and discusses the fundamental reasons influencing the changing price of the EUR/USD currency.

\section{THE USE OF TECHNICAL AND FUNDAMENTAL ANALYSIS IN FOREX MARKET}

The Foreign Exchange market (FOREX) is a place where buyers and sellers meet. Moreover, it is a place where supply and demand set the exchange rate $^{2}$. In 2001 daily FOREX turnover was 1.2 trillion US dollars. Since then until 2013, it peaked 4 times and reached 5.3 trillion $^{3}$. A few factors had a major impact on this huge jump of activity. Firstly, technological progress created an environment where investors and traders can make deals on laptops, computer tablets and mobile phones. Therefore, the FOREX market became available to all of us 24 hours a day and 5 days a week from almost any place on earth. Secondly, the retail FOREX brokers started providing financial services for low capital investors. Retail brokers have created new financial products ${ }^{4}$ which work with a large financial leverage. The daily turnover slightly decreased to 5.07 trillion USD in 2016. It is possible that a certain part of traders have chosen investing in cryptocurrencies instead of the regular currencies. The market value of main cryptocurrencies ${ }^{5}$ has risen from 10 billion USD in the beginning of 2016 to 30 billion USD in the second quarter of $2017^{6}$.

The FOREX market is different from the traditional financial markets because it has no physical trading place, such as New York Stock Exchange (NYSE) or Chicago Board of Trade (CBOT). However, the same methods of analysis used by the investor in the stock, bonds, funds or commodities markets can be adapted. The main ways to make a decision to invest in the financial market are the fundamental and technical analyses ${ }^{7}$. Fundamental

${ }^{2}$ C. Bartkus, Reliability Trends in Retail Foreign Exchange Brokers Market, „Ekonomiczne Problemy Usług" 2017, 2 (127).

${ }^{3}$ Foreign Exchange Turnover in April 2016, „Triennial Central Bank Survey” 2016, www.bis. org/publ/rpfx16fx.pdf

${ }^{4}$ A very popular product among the retail FOREX brokers is the Contract for Differences (CFD).

5 The most popular cryptocurrencies are Bitcoin, Ethereum, Monero, Litecoin.

${ }^{6}$ G. Hileman, M. Rauchs, Global Cryptocurrency Benchmarking Study, 2017, www.jbs.cam.ac. uk/fileadmin/user_upload/research/centres/alternative-finance/downloads/2017-global-cryptocurrency-benchmarking-study.pdf

7 C. Bartkus, Financial Markets, 2014, p. 47. 
analysis is based on economic ratios and indexes. Technical analysis is based on mathematical or statistical formulas and indicators. A trader's task is to select the right one.

Fundamental analysis is the study and interpretation of factors which influence the changing value of the analyzed financial object. The fundamental analysis has to see the object through a wide spectrum of factors and events. Such factors could be political events, changes in micro and macro economical situation. The main fundamental indexes in studies of the FOREX market are the Central Bank's Base Interest Rate (BIR), Inflation Rate (IR), Unemployment Rate (UR), and Gross Domestic Product (GDP). However, the fundamental analysis is suitable not only for monitoring indexes. A trader has to track the changes in fiscal policy of governments and monetary policy of central banks. The right interpretation provides an opportunity to forecast future economic situations. At the same time, these types of forecasts allow us to predict the future currency prices in the FOREX market. The most evident recent example is the Quantitative Easing $(\mathrm{QE})$ program. The $\mathrm{QE}$ is a simulation of an economy program in which the central bank purchases securities from the financial market. For the first time the phrase "Quantitative Easing" was mentioned by Japanese economists Ugai ${ }^{8}$ and Shiratsuka ${ }^{9}$ to describe the monetary policy followed by the Central Bank of Japan since 2001. During the QE, the amount of money grows until the consumer prices start rising. High goods prices promote the creation of new businesses and reduce unemployment. The start of the QE program means the depreciation of currency for country that chooses this monetary instrument. For example, in September 2014, president of the European Central Bank (ECB) Mario Draghi announced the beginning of the QE in the eurozone, starting January 2015. The Euro currency started losing its value to other major currencies straight after his announcement. The Euro against the US dollar lost 15\%, against the Great Britain pound $-\sim 12 \%$, against the Swiss Franc $-\sim 10 \%$ during the first year since Draghi's announcement.

The technical analysis is based on the past data; it is a method for the analysis and forecast of future prices, future trading volumes and tendencies of financial instruments. A technical analyst investigates the market without worrying about the fundamental factors ${ }^{10}$. The technical analysis tools are the indicators that can be divided into 4 groups:

1. Trend indicators. Securities prices can move in 3 directions: rise (uptrend), decline (downtrend) or stay stable (sideway trend). On the price line chart, uptrend is displayed as drown rising line. Downtrend is showed as drown declining line. The line is horizontal during the sideway trend in the market. The main aim of the trend indicators is indentifying trends as soon as possible. The indicators called "Parabolic Stop and Reverse", "Moving Averages", "Bollinger Bands", and "Moving Average Convergence Divergence" belong to this group.

2. Moment indicators. They can determine the situation in a finance market. In the situation when buyers dominate the market, prices always increase. Eventually the enthusiasm of buyers declines and they stop buying. This moment is called the "overbought market". Moreover, this moment signals about the possibility of price

\footnotetext{
${ }^{8}$ H. Ugai, Effects of the Quantitative Easing Policy: A Survey of Empirical Analyses, 2007, www.imes.boj.or.jp/research/papers/english/me25-1-1.pdf

9 Sh. Shiratsuka, W. Takahashi, K. Ueda, Financial System and Monetary Policy Implementation: Summary of the 2009 International Conference by the Institute of Monetary and Economics Studies of Bank of Japan, 2009, Tokyo: Discussion Paper No. 2009-E-20.

${ }^{10}$ Ch. Kirkpatrick, J. Dahlquist, Techninéanalizé, 2013.
} 
decrease. Vice versa, in the situation when sellers dominate the market, prices always decrease. Eventually the enthusiasm of sellers fades and they stop selling. Therefore, this moment is called the "oversold" market and it signals about the possibility of price increase. The indicators called "Relative Strength Index", "Stochastic Oscillator", and "Williams \% R" belong to this group.

3. Volume indicators. The volume indicators calculation methodology is based on the trading volume in the market. Important economic and politic events always affect the increase of the financial products trade. For example, if a certain company announces about a new technological invention, investors will hurry to buy shares of that company because of the expectation of bigger profit and dividends for the shareholders. The volume indicators determine when the trading volume exceeds usually frames. According to B. Dormeier" ${ }^{11}$, the indicators called "Money Flow Index", "Volume-Weighted Moving Average", and "Negative Volume Index" belong to this group.

4. Other indicators. These indicators that can be hardly assigned to the already described groups are characterized by the complexity of the calculating methodology. For example, the "Ichimoku Clauds" can show the market's trend, momentum, levels of resistance and support ${ }^{12}$. The next one, called the "Elliott Wave", is more of an investing philosophy or strategy than a simple indicator. R. N. Elliott believes that markets move in repeating cycles instead of chaotic directions. Cycles reveal themselves in five waves up and three waves down. After the first part of waves follows another five up and tree down. A trader can identify the cycle of market in present time, if he uses the "Elliott Wave" indicator properly.

The "Relative Strength Index" (RSI) has been chosen for the later described investigation for two reasons. Firstly, it is available on almost all PC, mobile and web trading platforms. Secondly, RSI is wildly observed in technical analysis books, articles and online forums. For index calculation, first of all, the Relative Strength (RS) has to be calculated:

$$
\mathrm{RS}=\mathrm{AUP} / \mathrm{ADP}
$$

where: RS - Relative Strength;

AUP - average gain of Up periods during the specified time frame;

ADP - average loss of Down periods during the specified time frame ${ }^{13}$.

The RSI inventor W. Wilder recommends using 14 days periods. The RS data of the $1^{\text {st }}$ formula has to be used in RSI calculation:

$$
\mathrm{RSI}=100-(100 /(1+\mathrm{RS}))
$$

${ }^{11}$ B. Dormeier, Investing With Volume Analysis. Indentify, Follow, and Profit from trends, 2013, http://ptgmedia.pearsoncmg.com/images/9780137085507/samplepages /0137085508.pdf

12 M. Patel, Trading with Ichimoku Clouds: The Essential Guide to Ichimoku Kinko Kyo Technical Analysis, 2010.

${ }^{13}$ L. Rakesh, P. Selvam, Relative Strength Index Application in Identifying Trading Movements of Selected IT Sector Companies in India, 2017, "International Journal of Management \& Business Studies", Vol.7, www.ijmbs.com/Vol7/vol7.1/7-p-selvam.pdf 
The calculated RSI value is always between 0 and 100. The aim of the indicator is to indicate the moment of the "overbought" market and the "oversold" market. If RSI goes above 70 (Figure 1), W. Wilder suggests calling this moment the "overbought" market. It is mean that desires of the securities buyers are satisfied and their enthusiasm starts to fade. Therefore, it is the moment of the so-called "Bear Market"14. Thus, in the FOREX market, a trader can make a "short" (sell) order for earning the profit of currency's depreciation.

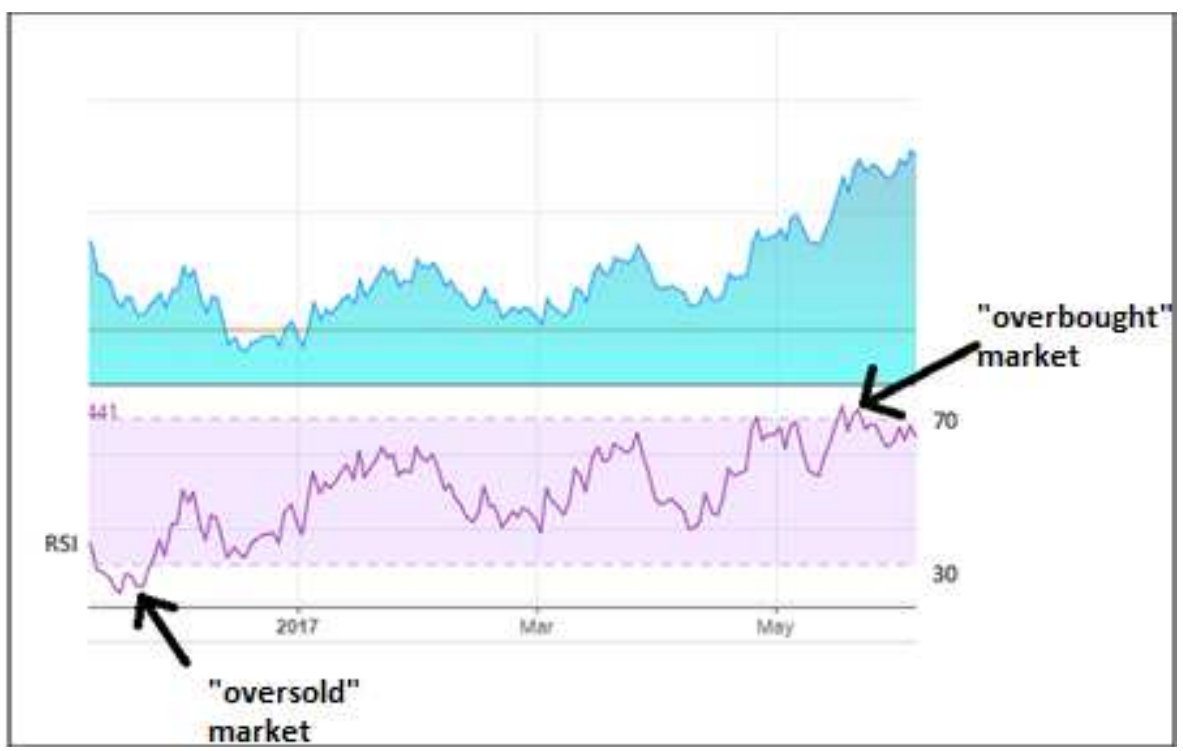

Figure 1. RSI signals of "overbought" and "oversold" market

It becomes the "Oversold" market when the RSI drops under 30 (Figure 1). It is the sign that the securities prices will be reversed and the so-called "Bull Market" 15 will begin. At the moment of the indication, a trader can make a "long" (buy) order and hope for profit of currency's value gain. Worth to mention, traders developed other techniques for interpretation of RSI value. One of those is the using of centerline for understanding the trend of price. The meaning of RSI's centerline is 50. The up-trend starts when RSI line crosses centerline from the bottom. The opposite crossing means down-trend. The RSI has certain disadvantages. The inventor and other researchers of this index do not recommend relying on it $100 \%$. W. Wilder has tested this index in the US stock market. He recommends using the RSI alongside with the divergence between price line and RSI line. His other recommendation is monitoring the resistance and support levels. A. Taran-Morosan ${ }^{16}$ reduced the highest level of RSI to 67.5 and increased the lowest level to 32.5 in his research. He asserts that the investment results of the US stock market are better than using the classic RSI.

${ }^{14}$ A „Bear Market” is a condition in which securities prices fall.

15 A „Bull Market“ is a condition in which securities prices rise.

16 A. Taran-Morosan, The Relative Strength Index Revisited, 2011, "African Journal of Business Management”, Vol.5, www.academicjournals.org/article/article1380724011_Taran-Morosan.pdf 
Ch. LeBeau ${ }^{17}$ applied the indicator in futures market. He suggests using RSI with 75 as the "overbought" and 25 as the "oversold" markets for better results. Most of index researches are done in stock or futures markets with modification of the classical RSI, i.e. the calculation based on 14 daily periods. Does the indicator work in the FOREX market? Is the classical modification suitable to analyze currencies? The most actively traded currency pair is the EUR/USD. That particular pair has taken $23 \%$ of the entire FOREX turnover in the year $2016^{18}$. The USD is the absolute leader in currency trading. Together with Euro and all the other currencies, it has been chosen by $88 \%$ of all trades. Euro was next, with $31 \%$, and Japanese yen was the third.

\section{TRADING THE EUR/USD PAIR WITH HOURLY RSI}

The FOREX market's most popular EUR/USD pair is chosen for future investigations. Imaginary trades have been made with the help of hourly RSI signals. Full conditions and rules for opening or closing trades have been described in Table 1.

Table 1. The rules and conditions for trading orders

\begin{tabular}{|c|c|c|c|c|c|c|c|}
\hline $\begin{array}{c}\text { Currency } \\
\text { Pair }\end{array}$ & $\begin{array}{c}\text { Entering } \\
\text { LONG } \\
\text { position }\end{array}$ & $\begin{array}{c}\text { Exiting } \\
\text { LONG } \\
\text { position }\end{array}$ & $\begin{array}{c}\text { Entering } \\
\text { SHORT } \\
\text { position }\end{array}$ & $\begin{array}{c}\text { Exiting } \\
\text { SHORT } \\
\text { position }\end{array}$ & $\begin{array}{c}\text { Trading } \\
\text { amount, } \\
€\end{array}$ & $\begin{array}{c}\text { Beginning } \\
\text { date }\end{array}$ & $\begin{array}{c}\text { Finishing } \\
\text { date }\end{array}$ \\
\hline EUR/USD & RSI $<30$ & RSI $>70$ & RSI $>70$ & RSI $<30$ & 1000 & 1.01 .2016 & 30.06 .2017 \\
\hline
\end{tabular}

However, some differences have been made to the classical RSI by using it with hourly periods instead of daily periods. The "Overbought" and "oversold" markets' conditions have left the classical RSI (Table 1). The long position is a transaction in financial markets when traders buy securities hoping that the price will rise. Imaginary $1000 €$ long orders were opened when RSI was under 30 and closed when RSI was above 70. The short position is a transaction in financial markets when traders sell securities hoping that the price will fall in the future. Imaginary $1000 €$ short orders were opened when RSI was above 70 and closed when it was under 30. The research period is 18 months from 1.01.2016 to 30.06.2017.

8 scenarios are simulated with 8 (H8), 10 (H10), 12 (H12), 14 (H14), 16 (H16), 18 (H18), 20 (H20) and 22 (H22) hourly periods. The H8 scenario had the biggest number of possible transactions. The sensitivity of RSI signals becomes lower in the cases when more periods are used in the calculation. Therefore, the $\mathrm{H} 22$ had 5 times less imaginary transactions (Table 2). Moreover, Table 1 shows that the $\mathrm{H} 8$ has been the leader in number of trades and had $56 \%$ of them that were correct. However, the total return was negative because of 6 very unprofitable trades. One of the biggest unprofitable transactions happened between 11.05.2017 and 18.05.2017.

${ }_{17}$ Ch. LeBeau, Technical Traders Guide to Computer Analysis of the Futures Market, 1991.

${ }^{18}$ Foreign Exchange Turnover in April 2016, „Triennial Central Bank Survey”, 2016, www.bis. org/publ/rpfx16fx.pdf 
Table 2. Trades results

\begin{tabular}{|c|c|c|c|c|c|}
\hline Scenario & Trades & Accuracy, \% & $\begin{array}{c}\text { Total return, } \\
€\end{array}$ & $\begin{array}{c}>2 \% \text { profitable } \\
\text { trades }\end{array}$ & $\begin{array}{c}>2 \% \text { unprofitable } \\
\text { trades }\end{array}$ \\
\hline H8 & 248 & 56 & -76 & 0 & 6 \\
\hline H10 & 182 & 50.5 & -113 & 0 & 5 \\
\hline H12 & 128 & 56.3 & -48 & 0 & 8 \\
\hline H14 & 94 & 60.6 & -20 & 2 & 7 \\
\hline H16 & 76 & 57.9 & -42 & 2 & 8 \\
\hline H18 & 58 & 58.6 & 102 & 4 & 5 \\
\hline H20 & 55 & 61.8 & 67 & 3 & 6 \\
\hline H22 & 51 & 64.7 & -63 & 3 & 8 \\
\hline
\end{tabular}

The RSI suggested selling the Euro when in his speech the ECB president M. Draghi expressed a very positive message for the Euro currency; that the QE will end soon ${ }^{19}$. Very similar situations happened in other 4 biggest RSI mistakes, i.e. the indicator showed a different direction than the ECB and FED heads suggested during their speeches. The Sixth big error occurred during the presidential elections in the US. The indicator suggested buying the EUR/USD pair; however, the news about the D. Trump's win raised the dollar.

The H10 experienced the largest losses (-113€) because of the lowest accuracy of trades $(50.5 \%)$. All the biggest losses happened in the same conditions as in the H8 scenario. Meanwhile, the $\mathrm{H} 12$ had one new factor in the biggest unprofitable trades account. The meeting of G7 leaders directed the EUR/USD to a different trend than the RSI. The H14 scenario reached $60.6 \%$ accuracy of trades with total losses of $20 €$. Together with the H16, the H14 scenario's RSI synchronized twice with fundamental events and gained over $2 \%$ of profit. However, both scenarios have 4 times higher number of the same size unprofitable transactions. The H18 is the most promising RSI modification with profit of $102 €$ and accuracy of $58.6 \%$. The main reasons of these results can be observed. Firstly, 4 trades have gained over $2 \%$ of profit and it is the best result among all the scenarios. Secondly, the H18 has the lowest (together with the H10) number of trades with over $2 \%$ of losses. 2 out of 5 such trades happened during M. Draghi's speeches. Other 3 belong to the J. Yellen announcement, the G7 meeting and France presidential elections.

TheH20 and H22 gained in accuracy, but lowered the profit accordingly to $67 €$ and $-63 €$. These scenarios increased the number of the most unprofitable trades and lowered the number of the most profitable trades to 3 against 4 of the H18. It is important to notice that the RSI's H22 modification has become insensitive and the few trades that continued for about 40 days brought bigger losses than usually. Table 3 shows that longer trade time means less accuracy.

In the $\mathrm{H} 8$ scenario, on the first day the opened and closed trades had $100 \%$ accuracy (Table 3). On the second day the accuracy slightly decreased to $87.5 \%$. However, these two days gained profit of $349 €$ with average $3 \%$ profitability per trade. For unclosed trades, troubles started after the second day when the accuracy started falling sharply. From this point of view, the reason of the $\mathrm{H} 8$ losses is trades which last longer than 2 days. Hence, for a better result, ways to get out of trades should be found on day 3 .

${ }^{19}$ M. Draghi, Introductory remarks at the House of Representatives of the Netherlands, 2017, www.ecb.europa.eu/press/key/date/2017/html/ecb.sp170510.en.html 
Table 3. Trade's results in aspect of time

\begin{tabular}{|l|l|l|l|l|l|l|l|l|l|}
\hline & $\mathbf{1}$ day & $\mathbf{2}$ days & $\mathbf{3}$ days & $\mathbf{4}$ days & $\mathbf{5}$ days & $\mathbf{6}$ days & $\mathbf{7}$ days & $>\mathbf{8}$ days & Total \\
\hline H8 & & & & & & & & & \\
\hline Trades & 36 & 80 & 41 & 30 & 26 & 17 & 9 & 9 & 248 \\
\hline Return, $€$ & 164 & 185 & -36 & 4 & -100 & -61 & -115 & -117 & -76 \\
\hline Accuracy, \% & 100 & 87,5 & 53,6 & 53,3 & 38,5 & 23,5 & 0 & 11,1 & \\
\hline H10 & & & & & & & & & \\
\hline Trades & 14 & 49 & 31 & 16 & 29 & 13 & 15 & 15 & 182 \\
\hline Return, $€$ & 74 & 194 & 25 & 10 & -52 & -42 & -104 & -218 & -113 \\
\hline Accuracy, \% & 100 & 89,8 & 65,5 & 75 & 58,6 & 30,8 & 6,7 & 13,3 & \\
\hline H12 & & & & & & & & & \\
\hline Trades & 8 & 30 & 15 & 11 & 12 & 12 & 13 & 27 & 128 \\
\hline Return, $€$ & 61 & 184 & 41 & 10 & -8 & 17 & -45 & -308 & -48 \\
\hline Accuracy, \% & 100 & 96,7 & 86,7 & 81,8 & 58,3 & 83,3 & 15,4 & 14,8 & \\
\hline H14 & & & & & & & & & \\
\hline Trades & 6 & 15 & 11 & 6 & 7 & 5 & 12 & 32 & 94 \\
\hline Return, $€$ & 68 & 125 & 50 & 26 & 42 & 20 & -6 & -345 & -20 \\
\hline Accuracy, \% & 100 & 100 & 100 & 100 & 85.7 & 80 & 41,7 & 18,8 & \\
\hline H16 & & & & & & & & & \\
\hline Trades & 2 & 11 & 9 & 4 & 1 & 7 & 10 & 32 & 76 \\
\hline Return, $€$ & 23 & 93 & 75 & 15 & 8 & 61 & 29 & -346 & -42 \\
\hline Accuracy, \% & 100 & 100 & 100 & 100 & 100 & 85,7 & 80 & 18,2 & \\
\hline H18 & & & & & & & & & \\
\hline Trades & 1 & 1 & 5 & 5 & 2 & 4 & 8 & 32 & 58 \\
\hline Return, $€$ & 27 & 9 & 62 & 58 & 36 & 45 & 19 & -154 & 102 \\
\hline Accuracy, $\%$ & 100 & 100 & 100 & 100 & 100 & 100 & 75 & 28,1 & \\
\hline H20 & & & & & & & & & \\
\hline Trades & 2 & 1 & 6 & 4 & 1 & 4 & 5 & 32 & 55 \\
\hline Return, $€$ & 44 & 10 & 89 & 28 & 9 & 47 & 29 & -189 & 67 \\
\hline Accuracy, \% & 100 & 100 & 100 & 100 & 100 & 100 & 100 & 31,3 & \\
\hline H22 & & & & & & & & & \\
\hline Trades & 1 & 1 & 4 & 6 & 2 & 3 & 6 & 28 & 51 \\
\hline Return, $€$ & 40 & 12 & 32 & 60 & 20 & 36 & 41 & -304 & -63 \\
\hline Accuracy, \% & 100 & 100 & 100 & 100 & 100 & 100 & 100 & 35,7 & \\
\hline
\end{tabular}

A very similar situation is with the H10 and H12, i. e. the accuracy was $100 \%$ in one day trades (Table 3) and the biggest part of profit was obtained in 1-2 days trades. The only difference is the longer period of days (4 days) with quite high accuracy $(>80 \%)$.

The H14 was $100 \%$ precise in the first 4 days and had accuracy over $80 \%$ in day 5 and day 6. The fact that 50 of 94 trades were made during this period is very promising. The H16 extended $100 \%$ precision up to 5 days and over $80 \%$ precision up to 7 days. During these 7 days, 44 transactions were made against 32 made beyond the first 7 days.

The H18 scenario gained the biggest profit of $102 €$. What helped doing that? We can see in the table 3 that $100 \%$ accuracy extended up to 6 days with $75 \%$ of accuracy in day 8 . But the amount of trades was lower than the amount of trades beyond 8 day: 24 against 32 . It is possible that fundamental reasons have made bigger impact to profitability than the 
time length. The scenarios $\mathrm{H} 20$ and $\mathrm{H} 22$ had similar tendency of lowering amount of trades during the days of high accuracy (Figure 2).

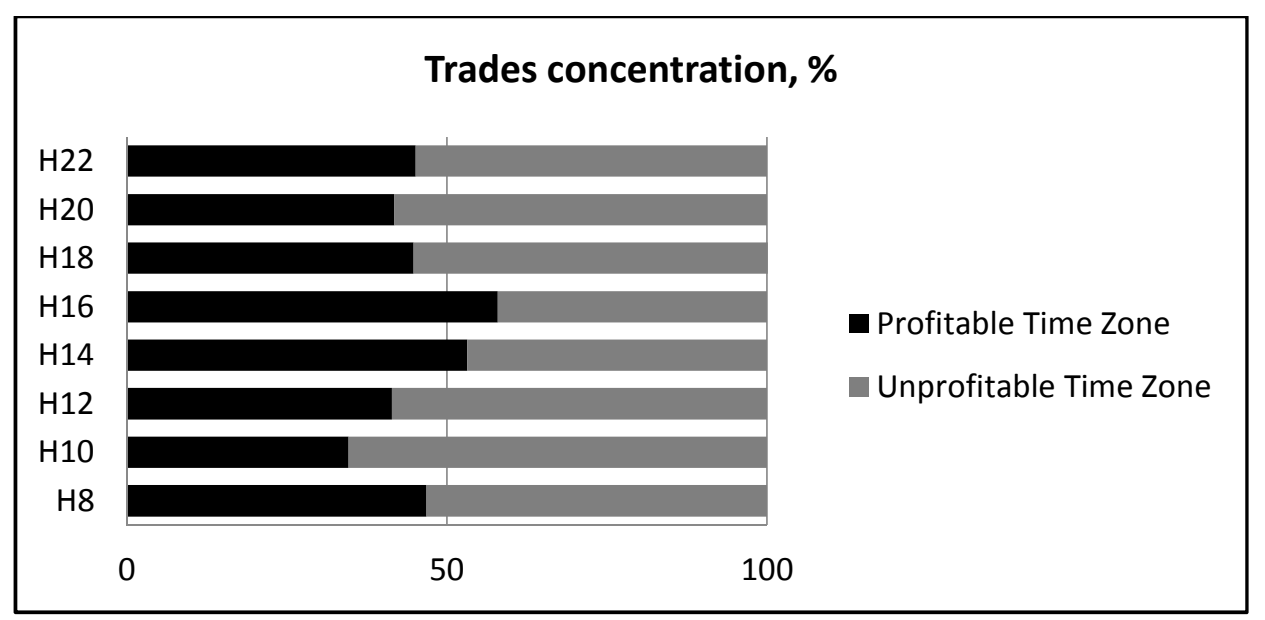

Figure 2. Trade concentration of all RSI modifications

The biggest part of transactions made in a profitable period of time is only in two scenarios: the H14 and H16 (Figure 2). Although, this result is good, less trades made in the unprofitable period of time brought bigger losses and a total negative return. The answer to the question of how the long lasting unprofitable trades can be identified as soon as possible will help to improve the results of return.

All the observed scenarios have positive and negative aspects. In active trading with RSI, the negative side is the index incapacity to predict the fundamental factors which impact the EUR/USD pair. Verbal interventions of heads of the ECB and FED along with elections of country leaders make RSI incorrect. However, the obtained data of some scenarios about the accuracy during the periods synchronized with the fundamental agenda could be valuable for the management of active trading portfolio.

\section{CONCLUSIONS}

1. Fundamental factors have an impact on the EUR/USD pair and the RSI accuracy. 7 out of 8 trading models with various RSI modifications experienced losses. Only the H18 had positive return during the period from 01.01.2016 to 30.06.2017. The biggest negative result received during the period of time was when the index forecasts coincided with the ECB, FED heads announcements, the G7 meeting and the presidential elections. The H18 had the least coincidences of this type (5) and the biggest portfolio profitability (10.2\%).

2. Results of better accuracy were obtained in the H14 and H16 RSI modifications when more than $50 \%$ of trades were made in the period of time with a precision above $80 \%$. Although, the perfect accuracy period of time increases together with the calculated number of periods in RSI, the number of trades decreases and gains a total negative 
return. The biggest problem for the $\mathrm{H} 14$ and $\mathrm{H} 16$ is a relatively large amount of trades with unprofitability over $2 \%$. In future, another RSI modification could be used for seeking less of trades and better control of currency based portfolio. For example, daily or weekly RSI modifications probably could be used in the similar trading scenarios. Rosillo, Fuente and Brugos ${ }^{20}$ investigated stock markets and concluded that most of the companies where RSI showed best results have big market capitalization in comparison to the rest. So, the same research could be applied for inactively traded currency pairs in the future. Such pairs have less capitalization and represent countries with less impact on global markets and economy. Herewith, the fundamental factors could do less damage to RSI signals.

\section{REFERENCES}

1. Bartkus C., Finansurinkos, Panevezys College, Panevezys 2014.

2. Bartkus C., Reliability Trends in Retail Foreign Exchange Brokers Market, EconomicsneProblemyUslug, Vol. 2 (127), 2017, Uniwersytet Szczeciński.

3. Dormeier B., Investing With Volume Analysis. Indentify, Folow and Profit from trends, Pearason Education Inc., 2013.

4. Draghi M., Introductory remarks at the House of Representatives of the Netherlands, European Central Bank 2017, http://www.ecb.europa.eu/press/key/date /2017/html/ecb. sp170510.en.html

5. Hileman G., Rauchs M., Global Cryptocurrency Benchmark Study, 2017, University of Cambridge.

6. Kirkpatrick Ch., Dahlquist J., Technineanalize, Smaltijosleidykla, Kaunas 2013.

7. Le Beau Ch., Lucas D., Technical Traders Guide to Computer Analysis of the Futures Market, McGraw-Hill Education, 1991.

8. Rakesh L., Selvam P., Relative Strength Index Application in Identifying Trading Movements of Selected IT Sector Companies in India, "International Journal of Management \& Business Studies” 2017, Vol. 7, http://www.ijmbs.com/Vol7/vol7.1/7-p-selvam.pdf.

9. Patel M., Trading with Ichimoku Clouds: The Essential Guide to Ichimoku Kinko Kyo Technical Analysis, John Wiley and Sons Inc., 2010.

10. Rosillo R., Fuente D., Brugos A., Technical analysis and the Spanish stock exchange: testing the RSI, MACD, Momentum and Stochastic rules using Spanish market companies, Applied Economics, Vol. 45, 2013, Taylor and Francis.

11. Taran-Morosan A., The Relative Strength Index Revisited, "African Journal of Business Management" 2011. Vol. 5, http://www.academicjournals.org/article /article1380724011_ Taran-Morosan.pdf

12. Triennial Central Bank Survey: Foreign Exchange turnover in April 2016,Bank of International Settlements, 2016, https://www.bis.org/publ/rpfx16fx.pdf.

13. Shiratsuka Sh., Takahashi W., Ueda K., Financial System and Monetary Policy Implementation: Summary of the 2009 International Conference by the Institute of Monetary and Economics Studies of Bank of Japan. Tokyo: Discussion Paper No. 2009-E-20, 2009.

\footnotetext{
${ }^{20}$ R. Rosillo, D. Fuente, A. Brugos, Technical analysis and the Spanish stock exchange: testing the RSI, MACD, Momentum and Stochastic rules using Spanish market companies, 2013, "Applied Economics", Vol. 45.
} 
14. Ugai H., Effects of the Quantitative Easing Policy: A Survey of Empirical Analyses, Bank of Japan, 2007, http://www.imes.boj.or.jp/research/papers/english/me25-1-1.pdf

15. Wilder W., New Concepts in Technical trading Systems. Hunter Publishing Company. North Carolina 1978.

\section{WYKORZYSTANIE WSKAŹNIKA SIEY WZGLĘDNEJ W CELU AKTYW- NYCH INWESTYCJI NA ZAGRANICZNYM RYNKU WALUTOWYM}

Rynek walutowy jest nieustannie dotknięty ogromną liczbą wydarzeń gospodarczych i politycznych takich jak decyzje banków centralnych, zmiany różnych wskaźników ekonomicznych, wybory, oficjalne ogłoszenia liderów krajowych itd. Różni inwestorzy, finansiści i naukowcy stworzyli wiele wskaźników, wzorów matematycznych i strategii inwestycyjnych w celu poprawy wyników inwestycji w instrumenty finansowe. W artykule przedstawiono i omówiono dane zebrane za pomocą indeksu względnej siły Wellesa Wildera, amerykańskiego analityka $\mathrm{w}$ transakcjach kasowych euro i pary amerykańskiego dolara. Wszystkie dane zebrano od 1 stycznia 2016 r. do 1 lipca 2017 r. i analizowano z kilku punktów widzenia. Celem tych badań było znalezienie najlepszej modyfikacji indeksu siły względnej w celu handlu na rynku FOREX. Badania odbiegały od klasycznego indeksu względnej siły do bardziej wrażliwych modyfikacji oryginalnej formuły. Osiągnięto osiem scenariuszy handlu z ośmioma różnymi modyfikacjami indeksu siły względnej. Tylko jeden z nich uzyskał pozytywny wynik, mimo że większość scenariuszy miała dokładność powyżej 50\%. W artykule przeanalizowano również przyczyny strat $\mathrm{w}$ transakcjach. Indeks był błędny, gdy wystąpiły silne fundamentalne czynniki, takie jak przemówienia szefów EBC i szefów FED. Błędy te spowodowały, że straty w transakcjach wyniosły ponad $2 \%$ nieopłacalności. Wszystkie prace opierały się na analizie literatury różnych autorów z różnych krajów i informacji od brokerów FOREX.

Słowa kluczowe: rynki finansowe, FOREX, wskaźnik siły względnej.

DOI: $10.7862 /$ rz.2018.mmr.39

Tekst złożono do redakcji: lipiec 2018 r.

Tekst przyjęto do druku: grudzień $2018 \mathrm{r}$. 
